\title{
Krisepost ved distriktspsykiatrisk senter reduserer ikke akuttinnleggelser i sykehus
}

\begin{abstract}
Sammendrag
Bakgrunn. På bakgrunn av vedvarende overbelegg i psykiatrisk akuttavdeling forsøkte vi å kanalisere akuttinnleggelser som var begrunnet i livskriser og ikke alvorlig psykisk lidelse, til et nytt kortids krisetilbud i distriktspsykiatrisk senter. Vi antok at det ville redusere innleggelsene i psykiatrisk akuttavdeling, og at denne endringen kunne avspeiles blant de innlagte på akuttavdelingen i form av høyere psykisk sykelighet.
\end{abstract}

\begin{abstract}
Materiale og metode. Studien har en kvasieksperimentell design. Pasientgrupper fra to opptaksområder innlagt ved psykiatrisk akuttavdeling ble sammenliknet $\mathrm{i}$ to perioder, før (2.1. 2003-1.6. 2003) og etter (2.1. 20041.6. 2004) etablering av en døgnbasert krisepost i distriktspsykiatrisk senter ved et av opptaksområdene.
\end{abstract}

Resultater. 234 pasienter ble inkludert. Antall innleggelser ble ikke redusert ved psykiatrisk akuttavdeling fra første til andre måleperiode fra noen av opptaksområdene. Det var gjennomgående redusert forekomst av psykisk sykelighet $\mathrm{i}$ andre måleperiode, dog kun hos menn i området med krisepost. Reduksjonen var størst ved selvskading og suicidal atferd $(p=0,02)$ og depresjon ( $p=0,01)$.

Fortolkning. Ingen av hypotesene ble innfridd. Hovedkonklusjonen er at pasientstrømmer i akuttpsykiatrien styres av mange komplekse og uforutsigbare faktorer. Helsevesenet endrer sin organisering kontinuerlig. Systematisk evaluering av slike tjenesteomlegginger er få, og de er vanskelige og ressurskrevende.

\section{Tone Bergerud}

tone.bergerud@sabhf.no

Allmennpsykiatrisk døgnseksjon

Psykiatrisk Senter Asker

Sykehuset Asker og Bærum

Postboks 83

1309 Rud

Paul Møller

FoU-enheten

Psykiatrisk klinikk

Sykehuset Buskerud

Frode Larsen

Psykiatrisk divisjon

Oslo universitetssykehus, Ullevål

\section{Marijke Veenstra}

Norsk institutt for forskning om oppvekst velferd og aldring

\section{Torleif Ruud}

Divisjon psykisk helsevern, Akershus

universitetssykehus

og

Institutt for psykiatri, Det medisinske fakultet, Universitetet i Oslo

Bakgrunnen for undersøkelsen er behovet for bedre styring av psykiatriske akuttinnleggelser til rett behandlingsnivå. De siste årene har man forsøkt å finne alternative behandlingstilbud for pasienter som innlegges i akuttpsykiatriske avdelinger. Vi ville undersøke om de minst syke pasientene systematisk kunne kanaliseres til et lavere behandlingsnivå for å redusere antall innleggelser i akuttavdelingene. Presset ved de psykiatriske akuttavdelingene er gjennomgående stort, og mange akuttavdelinger har hatt kraftig økning $\mathrm{i}$ antall innleggelser. Alternative tilbud forventes å kunne bidra til å redusere dette presset.

En del pasienter som blir innlagt i akuttavdelingene behøver kun et korttidsopphold i forbindelse med en livskrise, mens andre trenger utredning og lengre tids behandling. Likevel har det akuttpsykiatriske tilbudet vært lite differensiert. Pasienter med svært alvorlig psykisk sykdom, som schizofrenier og affektive lidelser, og mindre alvorlig psykisk sykdom, som krisereaksjoner, personlighetsforstyrrelser og lettere symptomlidelser, er oftest blitt lagt inn på samme avdeling, som oftest lukket avdeling. Disse akuttavdelingene er som regel utformet for å behandle psykotiske og til dels utagerende pasienter (1). En norsk undersøkelse har vist at $39 \%$ av pasientene i akuttavdelinger ble vurdert til å ha behov for andre tilbud i kortere eller lengre tid (2).

Alternative og mer differensierte akuttilbud er utviklet og forsøkt både her i landet og i våre naboland (3). Dels er det etablert mobile akutteam med sikte på å behandle pasienter uten innleggelser. Dels er det utviklet alternative døgntilbud i form av kriseposter i institusjoner eller kriseplasser i små enheter med mer hjemlig preg. En Cochrane-oversikt har vist at hjemmebasert kriseintervensjon kan være en akseptabel behandling for pasienter med alvorlige psykiske lidelser, men at det er behov for flere evalueringsstudier (4). I en norsk oversiktsartikkel konkluderer man med at det er behov for alternative akuttilbud, men at det er nødvendig med flere studier for å trekke sikre konklusjoner (5). Alternative tilbud som har vært studert, har ofte bestått av en kombinasjon av mobile akutteam og kriseplasser som disse disponerer. Det er derfor behov for egne studier av hhv. mobile team og kriseenheter med døgnplasser for å se hvilken spesifikk effekt disse kan ha (5), også når det gjelder pasienter som ikke er psykotiske.

Vi ønsket å se om det var mulig å redusere antall innleggelser i psykiatrisk akuttavdeling ved å opprette en ny korttids krisepost ved distriktspsykiatrisk senter, og om en slik krisepost ville bidra til å øke psykisk sykelighet ved den psykiatriske akuttavdelingen fordi de minst syke ville bli innlagt ved kriseposten.

\section{Materiale og metode}

Psykiatrisk klinikk ved Sykehuset Buskerud har fylkesdekkende ansvar og lokalsykehusansvar for Nedre Buskerud, med ca. 128000 innbyggere (2006) fordelt på fem kommuner. Akuttavdelingen ved sykehuset har to akuttposter og to subakuttposter med 51 døgnplasser. Drammen distriktspsykiatriske senter har lokalsykehusansvar for Nedre Buskerud og har polikliniske tjenester og to døgnenheter som dekker hvert sitt lokale opptaksområde

\section{Hovedbudskap}

- Det etableres nå nye akuttilbud i distriktspsykiatriske sentre, men hovedtyngden av akuttinnleggelser skjer fortsatt i de psykiatriske sykehusavdelingene

- Nye akuttilbud i distriktspsykiatriske sentre reduserer nødvendigvis ikke innleggelsene i psykiatriske akuttavdelinger 


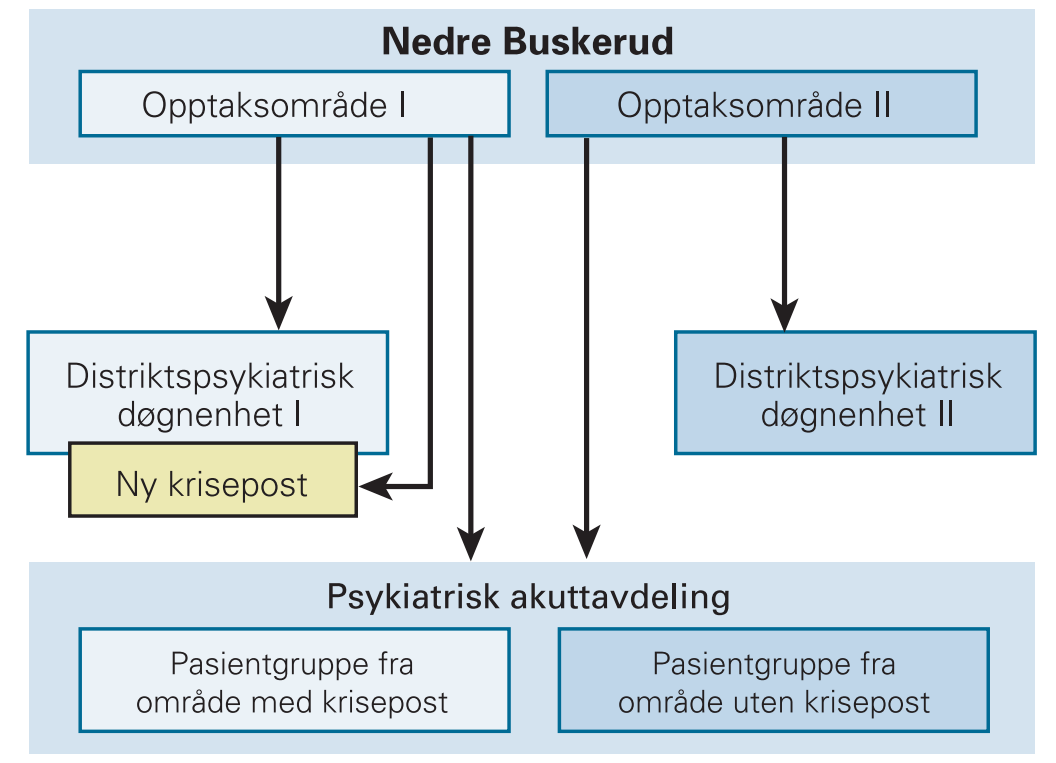

Figur 1 Pasientflyt til de distriktspsykiatriske døgnenhetene og psykiatrisk akuttavdeling

I studien ble pasienter fra Nedre Buskerud som ble innlagt ved akuttavdelingen ved Psykiatrisk avdeling kartlagt. Datainnsamlingen foregikk i to år fra 2.1. 2003-31.12. 2004, og omfattet 772 pasienter. Organisatoriske endringer, som omlegging av døgnplasser til dagplasser ved den ene døgnenheten ved Drammen distriktspsykiatriske senter, skjedde i siste halvdel av 2004. For å unngå at dette skulle påvirke resultatene, ble to sammenliknbare halvårsperioder valgt ut for analyse.

\section{Design}

Studien har en kvasieksperimentell design. Innleggelser ved akuttavdelingen fra to ulike opptaksområder ble sammenliknet $\mathrm{i}$ to perioder (fig 1). Periodene ble definert som før intervensjon (2.1. 2003-30.6. 2003) og etter intervensjon (2.1. 2004-30.6. 2004), der intervensjonen var etablering av en korttidspost på en døgnenhet ved Drammen distriktpsykiatriske senter høsten 2003. 234 pasienter, 110 før intervensjonen og 124 etter, ble inkludert etter følgende kriterier: innlagt i akuttavdelingen ved Psykiatrisk avdeling i løpet av de aktuelle periodene, folkeregistrert i Nedre Buskerud og alder 18-65 år. Mulige virkninger av intervensjonen ble kun målt på pasienter ved akuttavdelingen ved Psykiatrisk avdeling og disse ble analysert separat som to ulike pasientgrupper. Døgnenhetene ved Drammen distriktspsykiatriske senter mottok også i disse periodene pasienter fra samme opptaksområdene.

Ved kvasieksperimentelle design skal de pasientgrupper som sammenliknes være så like som mulig (6). Pasientgruppene fra de to opptaksområdene ble funnet å være sammenliknbare med hensyn til befolkningsgrunnlag i de to opptaksområdene (ca. 60000 innbyg- gere i hvert opptaksområde) og individuelle bakgrunnsvariabler i henhold til det nasjonale minste basis datasett. Videre hadde begge døgnenhetene ved Drammen distriktpsykiatriske senter før intervensjonen tilnærmet like innleggelseskriterier, behandlingstilbud og kapasitet (hhv. 26 og 28 døgnplasser) og mottok hovedsaklig elektive pasienter.

\section{Intervensjonen}

Ved den ene døgnenheten ved Drammen distriktpsykiatriske senter ble det i oktober 2003 åpnet en korttids krisepost med seks døgnplasser. Den skulle innen ett døgn ta imot pasienter som var kommet i en akutt livskrise og der poliklinisk tilbud ble vurdert som utilstrekkelig. Livskrise ble definert som en overveldende stressituasjon som personen utsettes for og hvor de vanlige mestringsstrategiene ikke er tilstrekkelige til å takle stresset (4). Oppholdet skulle ikke overskride tre uker. Kriteriene for innleggelse på kriseposten var bosted i området døgnenheten dekket (Lier, Røyken, Hurum, nordre bydel av Drammen), alder 18-65 år, vurdert til å ikke være suicidaltruet og til å kunne innlegges frivillig. Målet var å gi pasientene tid til å samle seg og mobilisere egne og nettverkets ressurser. Posten hadde ingen fast lege, men fikk daglig tilsyn av leger ved poliklinikken ved Drammen distriktspsykiatriske senter. Vurdering for innleggelse på kriseposten ble alltid foretatt av en lege tilknyttet behandlingsteamet ved poliklinikken.

\section{Instrumenter og reliabilitet}

Demografiske opplysninger ble registrert tilsvarende minste basis datasett (MBDS), som er obligatorisk i psykisk helsevern for voksne. Det ble gjort en klinisk vurdering av hver pasient med den todelte versjonen av Global Assessment of Functioning Scale (GAF) (7), som måler graden av symptombelastning og psykososialt funksjonsnivå. GAF er en kontinuerlig skala fra 1 (størst tenkelige grad av symptomer eller funksjonssvikt) til 100 (ingen symptomer eller funksjonssvikt). Type og alvorlighetsgrad innen 12 problemområder ble skåret på Health of the Nation Outcome Scales (HoNOS) (8). HoNOS-skårene er målt på en Likert-skala $0-4$ der 0 indikerer ingen problemer og 4 alvorlig til svært alvorlig problem. Skåringene ble gjort av sykepleiere som hadde fătt opplæring i HoNOS og GAF. Påliteligheten av skåringene (interraterreliabilitet ut fra intraklassekorrelasjon ICC) beregnet ut fra skåring av 20 pasientbeskrivelser, ble vurdert til å være tilfredsstillende med 0,83-0,93 for de HoNOS-skalaene som er tatt med i denne artikkelen og 0,73 for GAF.

\section{Statistikk}

Diagnosene ble kategorisert i seks hovedgrupper. Gruppene var små og ble gjort om til «dummy»-variabler og analysert i krysstabeller, for å se om det var statistisk signifikante endringer i diagnosesammensetningen før og etter intervensjonen. For å sammenlikne størrelsen og karakteristika på gruppene i akuttavdelingen før og etter intervensjonen ble det brukt khikvadrattester og t-tester. Når gruppene var mindre enn 30 , ble det brukt ikke-parametriske tester for å verifisere resultatene. Ved ulikt utfall ble resultatene fra ikke-parametriske tester benyttet. Endringene i psykisk sykelighet ble analysert separat for menn og kvinner. Aldersgruppene ble definert til under og over 35 år, som var gjennomsnittsalderen i vårt utvalg. Signifikansnivå ble satt til 5\%. Data ble analysert ved hjelp av SPSS 14.0.

\section{Godkjenning}

Undersøkelsen ble tilrådd av Regional etisk komité for medisinsk forskning i Helseregion Sør og Personvernombudet ved Norges samfunnsvitenskapelige datatjeneste.

\section{Resultater}

I halvårsperioden før kriseposten åpnet, ble 110 pasienter innlagt fra Nedre Buskerud til akuttavdelingen ved Psykiatrisk avdeling og 118 ved døgnenhetene ved Drammen distriktpsykiatriske senter. I tilsvarende periode etter etableringen av kriseposten, var det henholdsvis 124 og 183 innleggelser. Antall innleggelser økte på alle enhetene etter intervensjonen, men mest ved døgnenheten der kriseposten ble åpnet. I strid med forventningene økte antall innleggelser også ved akuttavdelingen i Psykiatrisk avdeling fra første til andre måleperiode. Antall innleggelser økte fra begge opptaksområder, og det var ingen statistisk signifikant forskjellig økning fra de to områdene (khikvadrat = $0,006, \mathrm{df}=1, \mathrm{p}=0,94)$. 
Karakteristika for pasienter innlagt i akuttavdelingen fra område med og uten krisepost før og etter etablering av kriseposten er vist $i$ tabell 1 . For alle som ble innlagt $\mathrm{i}$ akuttavdelingen $\mathrm{i}$ begge periodene var $45 \%$ menn, gjennomsnittsalder 35 år, 38\% mottok uføretrygd/sosialstønad, $30 \%$ ble tvangsinnlagt og $56 \%$ bodde alene. Pasientgruppene før og etter intervensjonen var ikke signifikant forskjellige når det gjaldt de nevnte sosiodemografiske faktorene. Basert på alle innlagte $\mathrm{i}$ akuttavdelingen hadde $26 \%$ schizofreni og $25 \%$ affektiv lidelse. Stoffrelatert lidelse, nevrotisk lidelse og personlighetsforstyrrelse forekom hos henholdsvis $16 \%, 14 \%$ og $12 \%$. Diagnosesammensetningen var stort sett stabil over tid unntatt for stoffrelaterte lidelser, der det var en statistisk signifikant økning av innleggelser fra intervensjonsområdet. For affektive lidelser var det signifikant nedgang fra området uten intervensjon.

HoNOS viste ingen statistisk signifikant forskjell i noen av problemområdene ved samlet analyse av totalmaterialet, men separate analyser etter kjønn viste forskjeller før og etter intervensjonen. Hos menn i intervensjonsgruppen var det, motsatt av forventet, gjennomgående redusert forekomst av psykisk sykelighet med henblikk på agitert adferd, selvskade og suicidal adferd, kognisjon og depresjon. Reduksjonen var størst ved selvskading og suicidal atferd (Mann-Whitneys test $p=0,02$ ) og depresjon (MannWhitneys test $\mathrm{p}=0,01)$. GAF viste ingen signifikant endring over tid i pasientgruppene, verken analysert samlet eller delt på kjønn og alder. Alder hadde ikke sammenheng med symptom- og funksjonsskår, og resultatene er derfor ikke tatt med her.

\section{Diskusjon}

Vi forsøkte å kanalisere akuttinnleggelser som var begrunnet i livskriser og ikke alvorlig psykisk lidelse, til et kortids krisetilbud i distriktspsykiatrisk senter. $\mathrm{Vi}$ antok at det ville redusere innleggelsene $i$ den psykiatriske akuttavdelingen, og at denne endringen kunne avspeiles blant de innlagte i form av høyere sykelighet. Ingen av disse antakelsene ble innfridd. Våre funn var overraskende, til dels motsatt av forventet og vanskelig å forklare.

Ut fra det vi kjente til, kunne vi anta at behovene for innleggelse var omtrent like store i de to opptaksområdene og at forholdene lå godt til rette for en kvasieksperimentell design. Sosiodemografiske karakteristika for pasientgruppene ble i tillegg sammenliknet før og etter intervensjonen og funnet rimelig like (tab 1). Vi antar derfor at funnene ikke i stor grad kan forklares ut fra forskjeller mellom områdene og pasientgruppene.

De uventede resultatene avspeiler trolig at det er komplekse mekanismer som styrer pasientstrømmen i akuttmedisinen generelt, og at disse derfor er vanskelig å studere. Gitt visse forutsetninger ville etableringen av et nytt krisetilbud til en selektert undergruppe av psykiatriske akuttpasienter, trolig kunne bidra til færre innleggelser ved de tradisjonelle akuttavdelingene. Når det ikke skjedde, tyder det på at noen av forutsetningene har sviktet. Vi vil peke på noen mulige forhold som kan ha vært av betydning.

De fleste akuttinnleggelser skjer på kveldstid, i helger og på helligdager (9). Pga. begrensede personal- og behandlerressurser kunne imidlertid pasienter bare tas imot på dagtid til kriseposten, noe som reduserte muligheten for å styre akuttinnleggelser utenom akuttavdelingen. På den annen side visste man av erfaring at mange pasienter i krise kan vente med innleggelse et døgn eller to dersom de var sikret et tilbud. Andre forhold enn pasientens tilstand kan imidlertid bli avgjørende for hvor og når innleggelsen må skje. Familieforhold, kjennskap til pasienten, kapasiteten ved det distriktspsykiatriske senteret, organisering av legevakt og mulighet til rask kompetent vurdering er noen faktorer som vil være av betydning.

De fleste innleggelser til kriseposten ble vurdert av og kom fra psykiatrisk poliklinikk, mens innleggelsene til akuttavdelingen i det vesentligste kom fra legevakt, fastleger og andre allmennleger. Beslutninger om innleggelse kan derfor ha blitt påvirket av ulik kjennskap til kriseposten, arbeidssted og faglig kompetanse.

Epidemiologiske undersøkelser viser at forekomsten av mennesker med psykiske problemer er mye større enn det antallet personer som innlegges eller henvises til psykisk helsevern $(10,11)$. Et nytt krisetilbud kan derfor lett åpne dørene for slike pasientgrupper, som ellers ikke ville hatt tilbud om innleggelse.

Tabell 1 Karakteristika for pasienter innlagt i akuttavdelingen fra område med og uten krisepost før og etter etablering av kriseposten, antall (\%)

\begin{tabular}{|c|c|c|c|c|c|c|}
\hline & \multicolumn{3}{|c|}{$\begin{array}{l}\text { Fra område med krisepost } \\
\text { før og etter etablering } \\
\text { av kriseposten }(n=110)\end{array}$} & \multicolumn{3}{|c|}{$\begin{array}{c}\text { Fra område uten krisepos } \\
\text { før og etter etablering } \\
\text { av kriseposten ( } n=124)\end{array}$} \\
\hline & $F \varnothing r$ & Etter & p & Før & Etter & p \\
\hline \multicolumn{7}{|l|}{ Sosiodemografisk } \\
\hline Menn & $33(55)$ & $29(43)$ & 0,19 & $18(36)$ & $25(44)$ & 0,41 \\
\hline Alder (gjennomsnitt (SD)) & $35(11)$ & 37 (13) & 0,34 & 35 (12) & $36(11)$ & 0,64 \\
\hline Uføretrygd/sosialstønad & $15(25)$ & 26 (39) & 0,18 & 19 (38) & $28(49)$ & 0,47 \\
\hline Bor alene & $30(53)$ & $45(68)$ & 0,08 & $26(53)$ & 30 (55) & 0,88 \\
\hline Tvungent psykisk helsevern & $23(38)$ & 25 (37) & 0,91 & $11(23)$ & $12(21)$ & 0,82 \\
\hline \multicolumn{7}{|l|}{ Hoveddiagnoser ICD-10 } \\
\hline Stoffrelaterte lidelser & $3(5)$ & $15(22)$ & $<0,01$ & $10(20)$ & $9(16)$ & 0,57 \\
\hline Schizofreni & $20(33)$ & $17(25)$ & 0,32 & $9(18)$ & $16(28)$ & 0,22 \\
\hline Affektive lidelser & $18(30)$ & $13(19)$ & 0,17 & $17(34)$ & $10(18)$ & 0,05 \\
\hline Angstlidelser & $9(15)$ & $4(6)$ & 0,09 & $8(16)$ & $12(21)$ & 0,50 \\
\hline Personlighetsforstyrrelser & $6(10)$ & $13(19)$ & 0,14 & $3(6)$ & $6(11)$ & 0,40 \\
\hline Andre/ingen diagnoser & 4 (7) & $5(8)$ & $1^{1}$ & $3(6)$ & 4 (7) & $1^{1}$ \\
\hline
\end{tabular}

Det er vanskelig å forklare hvorfor studien viste generelt redusert forekomst av psykisk sykelighet hos menn som kom fra området med krisepost. Diagnosefordeling og sosiodemografi var lik for kjønnene og gruppene. En mulighet kan være at menn generelt har høyere terskel for ta imot hjelp. Et nytt krisetilbud kan ha medført at en del menn fikk hjelp tidligere, eller at menn som tidligere ble avvist, likevel fikk hjelp og dermed ble innlagt før problemene ble mer alvorlige. At selvskade og suicidal atferd var et av problemområdene som viste størst reduksjon, er i tråd med et hovedfunn i TIPS-studien. Der ble det funnet at de som fikk hjelp tidlig, hadde signifikant færre selvmordstanker og -forsøk (12). Forskjellene er imidlertid små og når man korrigerer for multiple sammenlikninger, blir kravet til signifikansnivået justert til 0,008 (Bonferroni-justering), og et slikt konservativt nivå gir ingen statistisk signifikante endringer i HoNOS-skår.

\section{Konklusjon}

Utvikling av differensierte akuttpsykiatriske tilbud krever evaluering ved systematiske undersøkelser. Vår studie er en av de første slike systematiske evalueringer av alternative akuttilbud i Norge. I denne studien uteble den forventede reduksjonen av innleggelser på akuttavdelingen. Dette understreker behovet for slike studier. De svært komplekse sammenhenger i tjenestene kan tyde på at det er behov for større undersøkelser der man kan sammenlikne flere systemer.

Prosjektet er delfinansiert av Sosial- og helsedirektoratet, og SINTEF Helse har bidratt med veiledning. 


\section{Oppgitte interessekonflikter: Ingen}

\section{Litteratur}

1. Gjeldstad K, Løvdahl H, Ruud T et al. Tvangsinnleggelser til psykiatrisk observasjon - blir de opphevet dagen etter? Tidsskr Nor Lægeforen 2003: 123: $917-20$.

2. Husby R, Østberg B, Hartvig P. Får psykiatriske pasienter behandling på riktig omsorgsnivå? Tidsskr Nor Lægeforen 2003: 123: 1178-80.

3. Ruud T, Lindefors N, Lindhardt A. Current issues in Scandinavian acute psychiatric wards. Epidemiol Psichiatr Soc 2006; 15: 99-103.

4. Joy CB, Adams CE, Rice K. Crisis intervention for people with severe mental illnesses. Cochrane Database Syst Rev 2004; nr. 4: CD001087. http:// mrw.interscience.wiley.com/cochrane/clsysrev/ articles/CD001087/frame.html (15.6.2008).

5. Gråwe RW, Ruud T, Bjørngaard JH. Alternative akuttilbud i psykisk helsevern for voksne. Tidsskr Nor Lægeforen 2005: 125: 3265-8.

6. Shadish WR, Cook TD, Campell DT. Experimental and quasi-experimental designs for general causal inference. Boston: Houghton Mifflin, 2007.

7. Pedersen G, Hagtvet KA, Karterud S. Generalizability studies of the Global Assessment of Functioning - Split version. Compr Psychiatry 2007; 48: $88-94$.

8. Wing JK, Beevor AS, Curtis RH et al. Health of the Nation Outcome Scales (HoNOS). Research and Development. Br J Psychiatry 1998; 172: 11-8.

9. Deraas TS, Hansen V, Giæver A et al. Acute psychiatric admissions from an out-of-hours casualty clinic; how do referring doctors and admitting specialists agree? BMC Health Serv Res 2006; 6: 41.

10. Kringlen E, Torgersen S, Cramer V. A Norwegian psychiatric epidemiological study. Am J Psychiatry 2001: 158: $1091-8$.

11. Kessler RC, McGonagle KA, Zhao S et al. Lifetime and 12-month prevalence of DSM-III-R psychiatric disorders in the United States. Results from the National Comorbidity Survey. Arch Gen Psychiatry 1994: 51: 8-19.

12. Melle I, Johannesen JO, Friis S et al. Early detection of the first episode of schizophrenia and suicidal behaviour. Am J Psychiatry 2006; 163: 800-4.

Manuskriptet ble mottatt 9.1.2008 og godkjent 28.5.2009. Medisinsk redaktør Erlend Hem. 